\title{
COMO ROMANCEAR A REVOLUÇÃO OU A HORA PRÓXIMA, DE ALINA PAIM
}

Cíntia Schwantes/UnB

\begin{abstract}
Resumo: Alina Paim foi membro do Partido Comunista e a escritura de $A$ hora próxima obedece aos preceitos do realismo socialista. Sua publicação foi retardada em virtude da oposição enfrentada pelo grupo a que ela e o marido pertenciam e o grupo dominante dentro do Partido. Independentemente das intrigas de bastidor que cercaram a escritura e a publicação do romance, ele realiza um feito nada desprezível: o de seguir a linha ideológica do Partido, utilizando os pressupostos do realismo socialista, sem trair a matéria romanesca utilizada pela autora, uma greve que realmente aconteceu. Escrever um romance histórico é sempre tarefa delicada, e ainda mais quando as simpatias do escritor alinham-se com o lado que perdeu a luta. Fazer da derrota uma vitória, ainda que parcial é um exercício de, mais do que criatividade, fé. Em $A$ hora próxima, a vitória é algo para o futuro, e é apenas indicada, não se realizando dentro dos limites temporais da narrativa. Vale ressaltar, no romance em estudo, não apenas o fato de que ele se alinha em uma causa justa, mas também que o faz utilizando com maestria as técnicas literárias a sua disposição.
\end{abstract}

Palavras-chave: realismo socialista, literatura brasileira, Alina Paim.

Abstract: Alina Paim was a member of the Communist Party and the writing of her novel, $A$ hora próxima (The Coming Time) obeys the precepts of the socialist realism. Its publication was delayed due to the opposition her group faced, from the dominant group inside the Party. Regardless the intrigues surrounding its publication, the novel makes no small accomplishment: at the same time it follows the precepts of the socialist realism, and it does not betray the literary subject used by the author, a strike which actually occurred. To write a historical novel is always a tricky task, and even more when the sympathy of the author belongs to the defeated side. To turn defeat into victory, even if partial, is an exercise of, more than creativity, faith. $\ln A$ hora próxima, victory is placed in the future, and it is just hinted, not happening in the limits of the narrative. The novel then, allays itself to a good cause, and manages to do it utilizing very well the literary techniques available.

Key words: socialist realism, Brazilian literature, Alina Paim.

A trajetória de Alina Paim é extraordinária na medida que, órfã de mãe em tenra idade, entregue a um parente para que a criasse, submetida a uma educação rigorosa, ela consegue manter uma independência de pensamento tal que irá refletir mais tarde em suas escolhas, senão profissionais (dentro do 
permitido, à época, para as mulheres, ela se tornou professora), seguramente as políticas.

Filiada ao Partido Comunista do Brasil, Alina foi militante inclusive em sua atividade literária - é nesse esforço militante que se insere a escritura de seu romance "proletário", A hora próxima, publicado em 1955. Parte da coleção "Romances do Povo"1, dirigida por Jorge Amado, de quem ela era amiga pessoal, e publicada pela Editora Vitória, ligada ao Partido, não obstante, o romance enfrentou a censura interna do Partido ainda no auge da orientação zdanovista. Embora tenha sido recomendado por Jorge Amado, o romance teve sua publicação, esperada para 1952, retardada, em conseqüência da censura interna do Partido, em particular por causa da critica feita por Diógenes Arruda, que se alinhava com um grupo que se opunha ao de Alina e seu marido, Isaias Paim. Segundo Denis de Moraes, a escritora teve mesmo que modificar o romance para conseguir a aprovação para a publicação. Não estava sozinha nessa posição: o mesmo aconteceu, à época, a outro escritor filiado ao Partido, Dalcídio Jurandir.

Fiel à teoria da arte como reflexo objetivo da realidade elaborada por Lucáks, Alina conviveu durante um tempo com as mulheres que haviam participado da greve da Rede Mineira para recolher o material necessário para a escritura de $A$ hora próxima. Se Alina segue os passos de Jorge Amado na temática, uma vez que ele é o principal nome do realismo socialista na literatura brasileira, no tocante à forma, ela é muito mais estrita na aplicação dos princípios estéticos preconizados por Lucáks. Seu romance, para começar, assim como A condição humana, do também militante Andre Malraux, debruçase sobre um fato histórico já ocorrido e que pode ser interpretado, mas não modificado em sua essência.

A própria expressão "a hora próxima", utilizada por um dos personagens, o velho Tião, um velho militante, é uma referência à revolução. O velho, um militante saído das hostes do proletariado, cuja escola foi a vida dura e a primeiro volume da coleção, e vendeu 10 mil exemplares em sua primeira tiragem. 
solidariedade dos companheiros, se recusa a utilizar o vocabulário da cartilha marxista, preferindo, ao invés, palavras que tem ressonância na vida de proletários como ele, palavras às quais eles atribuem significado. Vale ressaltar que essa "fala do povo" é um dos pontos altos do romance, uma vez que remete não apenas ao fato de que a escritora realmente conviveu com os protagonistas de seu romance, mas também que seu texto abre espaço para a voz deles, como podemos constatar pelo seguinte trecho::

- ... Esse negocio de "latifúndio" e "reforma agrária" é coisa difícil para agregado. Tome segunda classe e puxe esses nomes, ninguém entende. Agora fale em "fazenda de léguas" e "alforria das terras", todo o mundo pega logo o assunto. Quem não se lembra de alforria? Escravo inda não é coisa de muito longe. Agregado sabe que a terra está no cativeiro, presa na mão do coronel. Quando se diz "alforria da terra" quem é que não descobre que é dar liberdade á terra, chegar um pedaço de roça para cada um? Se for um dia no Jornal [do Partido], inda faço esses reparos. (p.122)

Ao mesmo tempo, essa recusa da cartilha do partido, que é expressa por um velho militante cuja posição de proletário, o sal da terra, o coloca acima da possibilidade de condenação, não deve ter sido muito bem aceita pela cúpula do Partido. Esse foi, provavelmente, um dos problemas que o romance enfrentou para conseguir a aprovação do partido.

A ação se passa durante a greve de ferroviários da Rede Mineira de 1950. É também significativo que não apenas a ação inicial do romance é levada a cabo pelas mulheres, que formam os piquetes que obrigam os maquinistas a parar as máquinas, mas também esse é o fio condutor do romance: a ação das mulheres na continuidade da greve, sua organização, sua decisão, que torna o movimento possível, sua motivação (elas defendem seus maridos e, principalmente, seus filhos, que passam fome), sua coragem. Por trás da escolha romanesca, há um fato histórico: as mulheres eram encarregadas de encabeçar, ao menos de forma visível, os movimentos grevistas, uma vez que as empresas não poderiam despedi-las (elas não eram empregadas) nem tinham respaldo legal para despedir os maridos em virtude das ações das esposas. 
No entanto, o romance poderia ser organizado a partir de outros focos de ação. A opção por colocar as mulheres como foco primeiro da ação é também significativa, na medida que dá a elas um espaço privilegiado. Embora jamais tenha se engajado no movimento feminista, Alina Paim provou, ao longo de sua obra literária, não ser indiferente às questões relativas à condição da mulher sob o patriarcado.

A primeira locomotiva a ser parada, a 437, é rebatizada, e nesse movimento, humanizada: ela passa a ser chamada "Joana", um nome feminino, ao invés de ser identificada por um número. Ela é, também, enfeitada de flores, como uma noiva. Assim, o que está em jogo não é o trabalho - ninguém se ressente dele. São as relações de trabalho aviltantes, a falta de condições de segurança, o pagamento atrasado, a cooperativa que não fornece aos ferroviários e suas famílias os gêneros essenciais devido a uma negociata na qual a companhia adquirira a baixo preço um carregamento de macarrão cuja validade estava vencida. E em meio a essa luta ingente pela sobrevivência, os personagens têm vidas emocionais, se apaixonam, estabelecem relações de camaradagem e amizade, afirmam-se como pessoas de direito.

Alguns dados necessários para o entendimento do romance dizem respeito ao principal antagonista que os personagens enfrentam: a Rede Mineira. Em 1881, a Estrada de Ferro Oeste de Minas foi inaugurada, e depois, expandiu-se. No entanto, a empresa faliu e foi encampada, entre 1901 e 1931, pelo governo federal. Em janeiro de 1931, a estrada de ferro foi arrendada para o governo do Estado, fazendo parte da Rede Mineira de Viação, a Rede Mineira contra cuja administração as mulheres se mobilizam e iniciam a greve. Nos anos subseqüentes, enquanto a Central do Brasil trocava suas mariasfumaças por locomotivas a diesel-elétricas, muito mais rápidas e econômicas, as redes estaduais, como a de Minas e de Goiás, sofriam uma progressiva degradação.

Podemos escalonar os inimigos enfrentados pelo movimento grevista entre próximos, médios e distantes. Os próximos serão os delegados, inimigos políticos, engenheiros da Rede e os fura-greves; no nível médio encontramos a 
Administração da Rede, tanto em sua forma abstrata - pessoas a quem nunca ninguém viu e que não parecem ter uma existência concreta - quanto na forma dos engenheiros e administradores, e por fim, através das historias de vida dos personagens, o próprio sistema capitalista, aliás largamente denunciado, tanto pelos sofrimentos enfrentados por todos quanto diretamente, na fala dos muitos personagens que são filiados ao Partido.

O romance de Alina não sofre do problema denunciado por Lucaks na literatura soviética da época: na ausência de um sistema contra o qual lutar, de ameaças estrangeiras contra a soberania da URSS e de forças contrarevolucionarias ativas dentro do país, a literatura se via obrigada a recorrer a pequenos inimigos pouco relevantes e facilmente neutralizáveis no interior das fabricas e escritórios. Ao contrario, o Brasil da época era ainda mais pródigo em contradições e injustiças sociais do que hoje, e tornava fácil encontrar material para uma literatura engajada. Tanto que $A$ hora próxima, embora centrado na greve dos ferroviários, ao relatar a vida pregressa de alguns dos personagens, membros do Partido ou trabalhadores da Rede, expõe outras mazelas. A reforma agrária é um dos temas recorrentes, até por causa da predileção do Velho Tião, um personagem que ocupa um espaço maior no romance, por ele.

Outro dos princípios estéticos do realismo socialista utilizado por Alina em seu romance é justamente a presença do "herói coletivo". Assim, no desenrolar dos capítulos do romance, à medida que a greve avança, o leitor vai sendo introduzido à ação e as histórias de vida de vários personagens, um grupo deles em cada cidade que adere à greve. Se ao final da leitura é difícil lembrar de todos eles e de suas histórias pessoais, isso não deve ser visto como uma falha do romance; ao contrário. A intenção é justamente, ao mesmo tempo em que a narrativa abre espaço para trajetórias individuais, mostrar que a ação coletiva - a única que pode conduzir à real mudança da sociedade - só poderá ser levada a cabo coletivamente. No entanto, como não poderia deixar de ser, os personagens que mais retornarão ao longo do romance, e cujas falas são mais extensas, são naturalmente aqueles filiados ao Partido Comunista. 
Em sua seqüência, os capítulos mostram o alastramento de greve, ou retornam à narrativa dos locais onde ela já começou, mostrando sua evolução. Assim, cada cidade onde o movimento grevista estoura tem sua própria Comissão de Greve, eleita democraticamente, além de outros personagens que se engajam na greve, como "seu" Inácio, um comerciante que apóia a greve em Cruzeiro, o lugar de inicio da greve. Por outro lado, alguns personagens se opõe ao movimento grevista, como Manuel Barulho, um vereador do Partido Trabalhista que, em parte por questões partidárias e em parte por questões pessoais (ele alimenta uma grande animosidade em relação a Sílvio Ferreira, o membro do Partido que está ligado ao comitê de greve), procura solapar o movimento.

Os inimigos, como referido anteriormente, podem estar imediatamente presentes, como Manuel Barulho que, em um primeiro momento, procura desmobilizar a greve, afirmando estar a favor do movimento das mulheres, e argumentando que, como há a possibilidade de haver confronto violento com as forças da ordem, as crianças deveriam ser retiradas do acampamento de greve. Ora, como Sívio depois as faz ver, se as crianças fossem retiradas do acampamento, as mulheres também teriam que ir para suas casas, e então a mobilização da greve teria acabado. Em um segundo momento, depois que a comissão de greve consegue o apoio da prefeitura, sob a condição, imposta pelo prefeito, de não utilizarem a bandeira nacional nem fazerem passeatas, Barulho oferece-se para conseguir uma bandeira para as grevistas.

Outro inimigo próximo é o fura-greve João Olímpio, apresentado como um sujeito nervoso, assustadiço, e subserviente. O delegado de Cruzeiro, João Ranali, que gostaria de acabar com o movimento a baioneta e só não o faz porque não conta com efetivo suficiente, igualmente. $O$ engenheiro chefe da estação de Divinópolis é outro inimigo imediato, um homem que despreza a classe trabalhadora e reclama que o governo "dá asa" para os agitadores. $O$ delegado de Itajubá tenta jogar os ferroviários contra as mulheres, perguntando se eles agora não mandam mais em suas esposas. 
Embora nem todos os inimigos do movimento grevista sejam extensamente apresentados, alguns o são: Manuel Barulho é freqüentador de bordéis; o engenheiro pega a esposa em flagrante adultério e simplesmente transfere o cúmplice e a manda para o Rio com o pretexto de tratar da saúde. Assim, a moralidade dos personagens que são inimigos de classe é posta em causa: quem é incapaz de solidariedade humana e se posiciona a favor de uma sociedade injusta e desigual, o faz porque não possui os princípios morais mais básicos.

No segundo nível de forças que se opõe ao movimento grevista, está a própria Rede Mineira, com suas condições insalubres de trabalho, os salários atrasados, a falta no cumprimento dos acordos, as punições injustas. Em Divinópolis, o engajamento das mulheres se deve aos problemas que a Rede impõe a seus maridos e, portanto também a elas: Laura tem que costurar para fora por que o marido, Agenor, sofre sucessivas punições, injustas, com conseqüente desconto no salário, por que fez parte da Comissão de Salários na última greve. Conceição olha para o marido, cuja saúde se degrada nas más condições de trabalho na Rede e lembra de como ele era quando ela se apaixonou por ele:

Quem transformara seu homem dessa maneira? Com a vista turva, Conceição se curvava mais sobre o retrato [do marido jovem]. Quem, senão a Oficina da Rede Mineira? O trabalho maldito the envelhecera o marido, a máquina lhe decepara dois dedos, a fumaça e as fagulhas Ihe roubavam aos poucos a luz dos olhos. ... E Conceição, com o retrato nas mãos, odiou a Rede que mutilara seu homem e apagava a luz de seus olhos. (p. 173/174)

Por fim, o próprio sistema capitalista é denunciado como raiz de todos os males. Há extensas falas de personagens, principalmente os ligados ao partido, mas nem sempre, bem como digressões do narrador, que apresentam essas denuncias:

A estrada percorria léguas despovoadas, de terras sem cultivo que estavam em poder de poucos coronéis. Para o trem correr, ocupava homens, queimava combustível e se desgastava; se o trem não transportava mercadorias dava prejuízo. Logo o problema do prejuízo da Estrada de Ferro 
não era isolado, ao contrario, seguia paralelo com o da reforma agrária, da necessidade de dividir a terra com os camponeses. Se fosse observar os trechos de estrada que recebiam mais cuidados como renovação de material, dormentes e trilhos, conservação de pontes, descobria que esses trechos se encontravam quase sempre nas proximidades das jazidas de minérios. Os trens, aí, serviam no transporte de minérios até os portos de embarque para o estrangeiro. Por que os minérios governavam a escolha dos trechos de conservação da estrada? Para que se destinavam esses minérios e a quem interessavam?adquiriam tanta importância os minérios porque eram utilizados na corrida de armamentos, na preparação da terceira guerra. Minérios estratégicos eram embarcados para os Estados Unidos a preço ridículo. E por que o governo consentia nisso, não via a manobra? Via perfeitamente e consentia porque estava comprometido até a raiz dos cabelos com o Departamento de Estado Norte-Americano. Isso levava à guerra? Aí estava o ponto vital. Naquele momento nenhuma luta era desligada do problema da guerra e da paz, da defesa das liberdades, do combate ao imperialismo americano. (p. 316/317)

Esse trecho, embora venha na voz do narrador, expõe a explicação que Eugenio, provavelmente um nome falso, o homem do Partido que vai a Cruzeiro a pedido de Sílvio, dá aos grevistas. Não apenas as idéias são consistentes com o ideário do Partido na época, como também a fórmula de utilizar perguntas que, quando respondidas, seja pelo orador seja pela platéia, conduzem a um encadeamento de idéias cujo fim é denunciar as mazelas do capitalismo, também era correntemente utilizada.

Outra instituição que apóia os grevistas é a imprensa. Vale lembrar que Marx afirmava que uma imprensa livre era uma força a serviço da democracia (e, portanto, da revolução). Nascimento, amigo de Sílvio, dono e repórter da Rádio Mantiqueira, faz a cobertura da greve, com evidente simpatia pelo movimento. Em um dado momento, ele é procurado pelo delegado, que ameaça veladamente, fechar a rádio caso os boletins continuem. Ele, no entanto, é um legítimo representante da imprensa livre: embora não simpatize com o comunismo, julga justa a luta das mulheres, e pretende, mesmo após a ameaça, continuar com a cobertura da greve. 
Por outro lado, o anti-clericalismo é denunciado mais de uma vez como incompatível com o verdadeiro espírito comunista. Vários dos personagens têm fé e levam uma vida religiosa, não apenas as mulheres, como Julinda e Cida, mas também muitos dos homens, como o velho Tião, ou Zé de Barros, declaram-se pessoas de fé. Por outro lado, nem sempre os padres estão do lado dos operários. O padre João, sabidamente simpático ao Partido Integralista, tenta convencer as mulheres a voltarem para casa e acabarem 0 movimento, e ante sua recusa, pergunta se elas viraram hereges. Ao que a companheira Marta, filiada ao partido, retruca que não, que se ele puxar reza, todas rezarão, mas que só abandonarão a Estação Ferroviária mediante atendimento de suas reivindicações.

Outra instituição que é salvaguardada no decorrer do romance é o Exército. $\mathrm{O}$ coronel que vai com seu destacamento para restabelecer a ordem no acampamento de greve em Cruzeiro, comove-se com a situação das mulheres, algumas com filhos doentes e sem condições de medicá-los:

... No ombro de uma mulher uma criança chorou, e o choro desconsolado,
escorrendo sem força, aumentou-lhe [ao coronel] a indecisão. A mão da
mulher batia de leve nas nádegas da criança, tentando acalma-la, sufocar
aquele choro que atraia sobre os dois os olhares do acampamento. ... A
criança se aquietou e os olhos da mulher cruzaram-se com os dele, cheios
de desculpas. Uma onda de constrangimento avermelhou as faces do
coronel. Como puderam o prefeito e o delegado julga-lo capaz de atirar os
soldados contra mulheres e crianças? Seu batalhão se cobriria de
vergonha virando covardemente baionetas contra mulheres e crianças. ...
(p.134/135)

Sua ação, então, acaba sendo em favor da greve: os soldados ficam de vigia para que não ocorram tumultos, o que ajuda a comissão de greve, que havia destacado grupos de homens para ficarem de vigia durante a noite para impedir invasões ou vandalismos. O coronel ordena mesmo que alguns mantimentos sejam encaminhados para o acampamento. Por fim, há uma confraternização entre grevistas e soldados, que afinal também são filhos da classe proletária. 
Vale ressaltar que no capítulo 6, temos uma personagem feminina, chamada Nina, que é destacada pelo Partido para fazer parte de um esforço de condução da greve em Divinópolis. Ela e seu irmão, Milton, vão à cidade com missões diferentes: ele deve panfletear, por folhetos falando sobre a greve em andamento e seus motivos, sob as portas das casas do bairro ferroviário. Ela, mais experiente, deve entrar em contato com as mulheres dos ferroviários e ajuda-las a organizar a greve.

Tendo trabalhado como tecelã e participado de movimentos grevistas anteriormente, ela se sente preparada para a missão, embora cada viagem determinada pelo Partido traga para ela o problema da separação da filhinha. No entanto, mesmo essas separações, penosas como possam ser, tem um lado positivo: a "família" se amplia, pois a menina fica em casas de companheiras do Partido, que se tornam "tias" por afeto. Essa passagem é importante, pois o movimento grevista fora deflagrado pelos próprios ferroviários de forma quase espontânea, e sem a necessária organização, que seria provida, é claro, pelo Partido.

Assim, a ação do Partido, uma vez iniciada a greve, é a de tentar organizar o movimento para garantir o seu sucesso. Esse será um dado importante no final do romance. Ainda é interessante ressaltar que Alina era chamada Lina pelas pessoas próximas, o que nos permite, até pela aproximação fonética dos nomes, inferir que essa personagem tem um traço autobiográfico em sua constituição. Mais adiante no romance, os companheiros do Partido, Milton inclusive, serão presos, e Nina ira se angustiar com a possibilidade de, sob tortura, o irmão acabar revelando alguma informação à polícia, mas se tranqüiliza por ter certeza de o "silencio de um comunista" é "uma fortaleza". Novamente, temos a convicção, expressa no romance, de que os comunistas estão, de alguma forma, acima das fragilidades humanas. De forma semelhante, os militantes, mesmo quando não tiveram muito acesso ao estudo, sempre vêem mais claro que seus companheiros e tem uma resposta para cada situação. 
Outro desdobramento importante da prisão dos militantes em Divinópolis é que o fato torna possível aos companheiros perceberem a sua causa, criticala e corrigi-la. $O$ erro fora o isolamento das massas, e do revés sofrido tira-se uma lição, um dos princípios do Partido:

... Para isso, os comunistas têm como norma: encarar pela frente tanto as
vitórias quanto os revezes, sem temor de reconhecer um erro, porque muitas
vezes num passo atrás se acumula a energia de dois passos para adiante.
(p. 338)

Durante as movimentações da greve, as personagens têm suas vidas pessoais se desenrolando, ao mesmo tempo. João Luis, o sobrinho de um velho militante, Zé de Barros, está apaixonado por Anica, a viúva do ferroviário Cardosinho, morto em um acidente de trabalho, quando o filho era pequeno. $O$ menino fica com a mãe no acampamento de greve, e João Luis se aproxima dele como forma de se aproximar da mãe. Ela percebe que o filho precisa de um pai, e que gosta de seu pretendente, e quando confrontada por ele, decide que pode refazer sua vida ao lado dele. De forma análoga, Geraldo, apaixonado por Margarida, filha do grevista Lino Marques, engaja-se na greve por causa da amada, e é a solidariedade da greve que acaba por the permitir se aproximar do pai da moça e pedir permissão para corteja-la. Assim, o tecido das vidas emocionais dos personagens se entrelaça com o movimento da greve.

Vida pessoal, portanto, corre paralela a vida política dos personagens. Assim é que Sívio Ferreira, o homem do partido, que toma as decisões mais sábias quanto à condução da greve, nem sempre o faz em sua vida pessoal. Casara-se apaixonado pela mulher; no entanto, como ela era muito religiosa, ele passara a criticar a lgreja e a ironizar a fé da mulher. Isso provocara um progressivo afastamento entre eles. Ao testemunhar o apoio que as esposas dos ferroviários dão aos maridos durante o movimento grevista, ele sente agudamente a ausência de sua familia: o velho Zé de Barros conta com a presença da esposa, Julinda, e da filha, a quem ele orgulhosamente chama de "companheira Marta". A filha de Lino Marques toma parte nas atividades, e ao mesmo tempo procura dar apoio à madrasta, que não pudera participar devido 
à gravidez avançada (o bebê nasce durante a greve). Ao final do romance, ele decide que irá reconquistar a esposa, e prefigura futuras greves nas quais poderá contar com o apoio dela. Assim, o homem do partido é humanizado ele também comete erros, mas em um aspecto de sua vida onde eles não terão impacto negativo sobre seus companheiros - e, principalmente, é capaz de aprender com seus enganos e corrigi-los.

O final do romance é muito engenhoso: a greve não poderia ser um fracasso, visto como lutava por uma causa justa, a causa do proletariado. Por outro lado, não tendo sido organizada pelo Partido, tampouco poderia ter sido um sucesso. Assim, a narrativa opta por uma solução de compromisso:

- ... Se teve vitória ou não se teve?

- Vitória, d. Elisa, mas vitória pela metade, se tirou o acordo sem o aumento - respondeu Hortênsia. (p.346)

A derrota parcial da greve estava anunciada, para o leitor atento, desde o início: ao se eleger a comissão de greve em Soledade, tomam parte dela Maria José, Iracema e Lourdes, esposas do agente, do gerente da cooperativa e do conferente, respectivamente. O Superintendente da Rede Mineira pede para conferenciar com a Comissão de greve em um lugar reservado, e como a Comissão fora composta por cinco pessoas, Marieta e Hortênsia, mulheres de ferroviários, acabaram sendo voto vencido; uma vez que a greve havia acabado em uma das estações, era inútil tentar manter o movimento nas outras. Assim, não há traição dentro da classe operária; há apenas falta de organização, algo que pode ser remediado com uma presença maior do Partido dentro das organizações de trabalho da Rede, o que se torna compromisso do Partido a partir daquele momento. O romance termina prefigurando uma nova greve, na qual as lições aprendidas permitirão uma vitória total do movimento operário.

Uma das crianças morre ao final da greve, e a dor da mãe repercute nos companheiros, que assumem o compromisso de não permitir que outras crianças morram por falta de condições de vida e cuidados médicos adequados. Essa passagem é considerada piegas, uma fragilidade no tecido 
do romance. No entanto, ela realça os valores da maternidade, parte fundamental da estrutura patriarcal e portanto amplamente respeitadas. Vale lembrar que um grupo de mães enfrentou uma das mais sanguinárias ditaduras do Cone Sul.

Independentemente das intrigas de bastidor que cercaram a escritura e a publicação de $A$ hora próxima, o romance realiza um feito nada desprezível: 0 de seguir a linha ideológica do Partido, utilizando os pressupostos do realismo socialista, sem trair a matéria romanesca utilizada pela autora, uma greve que realmente aconteceu. Escrever um romance histórico é sempre tarefa delicada, e ainda mais quando as simpatias do escritor alinham-se com o lado que perdeu a luta (caso, igualmente, de $A$ condição humana). Fazer da derrota uma vitória, ainda que parcial (no romance de Malraux, a derrota na tentativa de levar a cabo uma revolução socialista na China é apenas um momento da luta, mas isso não pode transparecer dentro dos limites do enredo. Como no romance de Paim, a vitória é algo para o futuro, e é apenas indicada, não se realizando dentro dos limites temporais da narrativa) é um exercício de, mais do que criatividade, fé. Assim, vale ressaltar, no romance em estudo, não apenas o fato de que ele se alinha em uma causa justa, mas também que o faz utilizando com maestria as técnicas literárias a sua disposição.

\section{BIBLIOGRAFIA}

COUTINHO, Carlos Nelson. Literatura e humanismo. Rio de Janeiro: Paz e Terra, 1967.

KONDER, Leandro. Os marxistas e a arte. Rio de Janeiro: Civilização Brasileira, 1967.

CARDOSO, Ana Leal. Marcas do feminismo em Alina Paim. In CARDOSO, Ana Leal e GOMES, Carlos Magno (orgs). Do imaginário às representações na literatura. São Cristóvão: EdUFS, 2007.

LUCAKS, Georg. Realismo crítico hoje. Brasilia: Coordenada, 1969.

Brasileira, 1968.

Marxismo e teoria da literatura. Rio de Janeiro: Civilização

MORAES, Denis de. O imaginário vigiado. Rio de Janeiro: José Olympio, 1994. kplus.cosmo.com.br/materia.asp?co=296\&rv=Literatura consultado em 22/08/2008

PAIM, Alina. A hora próxima.Rio de Janeiro: Vitória, 1955. 